\title{
NEW SPECIES OF DIPTERA FROM NORTH CAROLINA AND FLORIDA
}

By Charles W. Jominson.

Boston Society of Natural History.

The following descriptions of the species from Florida have been taken from the manuscript of a supplementary list of the Diptera of Florida, which it seems undesirable to publish at present when so much still remains to be done on the insect fauna of that state.

\section{Macrocera floridana sp. nov.}

$\sigma^{7}$. Head yellow, ocelli black, antennæ brown, base yellow. Thorax yellow, with three broad shining brown stripes, the lateral ones shortened anteriorly. Abdomen yellow. Halteres and legs yellow, tarsi brown. Wings hyaline, slightly tinged with yellow, veins brown, a single brown spot is present at the bases of the submarginal and first and second posterior cells; only a small portion of the spot is in the first posterior cell, the slight brownish tinge at the tip of the wing is entirely due to minute hairs. Length $4 \mathrm{~mm}$.

Two specimens. St. Augustine, Fla., April 16 and 17, 1919.

This species is related to M.clara Loew, but is separated by the absence of brown at the apex of the wing and at the stigma and the smaller clouding at the center of the wing.

\section{Psilocephala subnotata sp. nov.}

$0^{7}$. Face and front black, entirely covered with a whitish pollen, in certain lights showing two dark spots above the base of the antennæ, eyes narrowly separated, about one third as wide below the ocelli as at the vertex, antennæ and proboscis black. Thorax blackish with light gray vittæ bordering a dark central stripe, pleura and scutellum black grayish pollinose, the latter with four black marginal bristles. Abdomen black with dense silvery white pollen and white hairs, the third and fourth seg- 
ments only with shining black spots on the sides, the one on the third small while that on the fourth extends entirely across the segment; genitalia reddish with yellow and black hairs. Legs yellow, tips of the femora, tibiæ and tarsal joints brown. Halteres dark brown. Wings yellowish hyaline, veins and stigma light brown. Length $5 \mathrm{~mm}$.

․ Face and front entirely whitish pollinose, the latter above the antennæ about one third the width of the head and at the ocelli one sixth. Thorax as in the male. Abdomen shining black, with black hairs, posterior margins of the first, second, and third segments with a narrow border of silvery pollen and white hairs, fifth and sixth with a white pollinose spot on each side, tip of the abdomen dark brown with black hairs, otherwise like the male. Length $8 \mathrm{~mm}$.

Two specimens, St. Augustine, Fla., April 12 and 18, 1919. Types in the author's collection.

Taken by the writer in company with $P$. notata Wied., with which it was at first confused. It is readily separated by its. smaller size, the eyes not contiguous in the male, and the front entirely pollinose in both sexes.

Psilocephala davisi sp. nov.

$\sigma^{7}$. Face black whitish pollinose, hairs on the lower part of the face and inferior orbits white and much longer than in closely related species, front black whitish pollinose except the extreme upper and narrow part of the triangle which is shining black; first antennal joint black, the others dark brown. Thorax and scutellum black with long grayish hairs, dorsal stripes obsolete, the white hairs on the pleura long with dense tufts before the squamæ. Abdomen black, hairs white, forming dense tufts on the sides of the first and posterior margins of the second and third segments, the margins of which are also narrowly whitish pollinose, the shining spots on the sides of the second, third, and fourth segments conspicuous. Genitalia reddish with white hairs Femora black, hairs white, bristles black, tibiæ yellow, tips brown, base of the tarsi yellow, tips of the meta-tarsi and the remaining joints dark beown. Halteres black. Wings hyaline, 
veins near the base yellow, stigma and outer portion of the veins brown. Length $8 \mathrm{~mm}$.

One specimen, Southport, N. C., April 10, 1914. Dedicated to its discoverer, Mr. William T. Davis.

The species might be confused with either $P$. homorrhoidalis Macq. or $P$. frontalis Cole. It is, however, more robust, with longer pile and narrower pollinose bands on the posterior margins of the abdominal segments. . The shining black of the front is confined to the extreme upper point of the triangle.

\section{Mixogaster delongi sp. nov.}

․ Head red, facial vitta brown, ocelligerous triangle black, front with a pair of longitudinal ridges on each side midway between the base of the antennæ and the orbits, antennæ red, the first and second joints together not quite as long as the third, the latter spatulate, about twice as wide near the tips as at the base, arista yellow, base black. Thorax: disc black with two narrow brown lines joined to a brown spot in front of the scutellum, lateral margins and a large spot on the pleura below the wings red, humeri, a small spot at the transverse suture, a large Vshaped mark on the pleura and the scutellum yellow, a spot in the the middle of pleura, the sternum and metanotum black. Abdomen, first segment yellow, second red, margined posteriorly with yellow, third and fourth brownish-black margined poste riorly with red and yellow. Genitalia reddish. I.egs red, the basal half of all the tibiæ yellow. Halteres yellow. Wings brown, the costal and greater portion of the first and second basal and discal cells yellow. Length $11 \mathrm{~mm}$.

One specimen, Paradise Key, Fla., April 6. Dedicated to Dr. D. M. DeLong, who collected this interesting species. A specimen has also been taken by Mr. H. C. Fall, Dunedin, Fla., Mar. 22, 1925.

Chaetopsis brooksi sp. nov.

9. Head brown, the entire orbital margins whitish, ocellar triangle and sides of the vertex bluish, metallic, first and second 
joints of the antennæ yellow (third joint missing). Thorax bluish, shining, and slightly pruinose, an obscure dorsal stripe, pleura and scutellum brown; the pleura shows in certain light. a bluish metallic lustre. Abdomen blackish, shining, base brown. Legs brown, the tibiæ and tarsi slightly darker than the femora. Halteres light yellow. Wings brownish, with a whitish hyaline spot, partly in the first and partly in the second posterior cells about halfway between posterior cross vein and the edge of the wing, a middle whitish band extends from the costa across the discal cell and into the third posterior cell but not quite reaching the posterior margin, base of the wing hyaline. Length $4 \mathrm{~mm}$.

Two specimens collected by Mr. W. Sprague Brooks at Paradise Key, Fla., Feb. 25, 1920. The species is readily separated from the other American forms by its peculiar wing pattern, which resembles that of $C$. angustata Hendel from Brazil. 

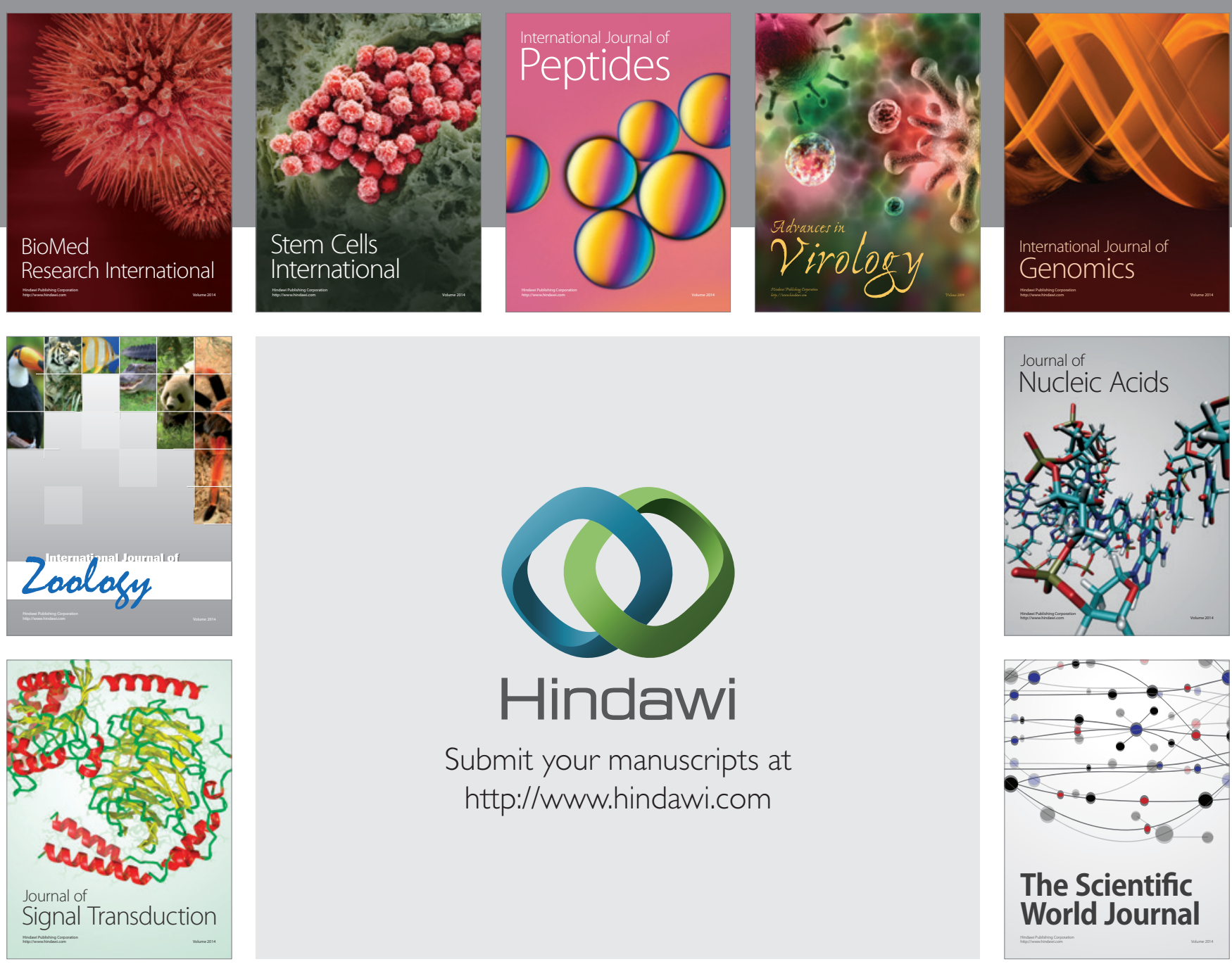

Submit your manuscripts at

http://www.hindawi.com
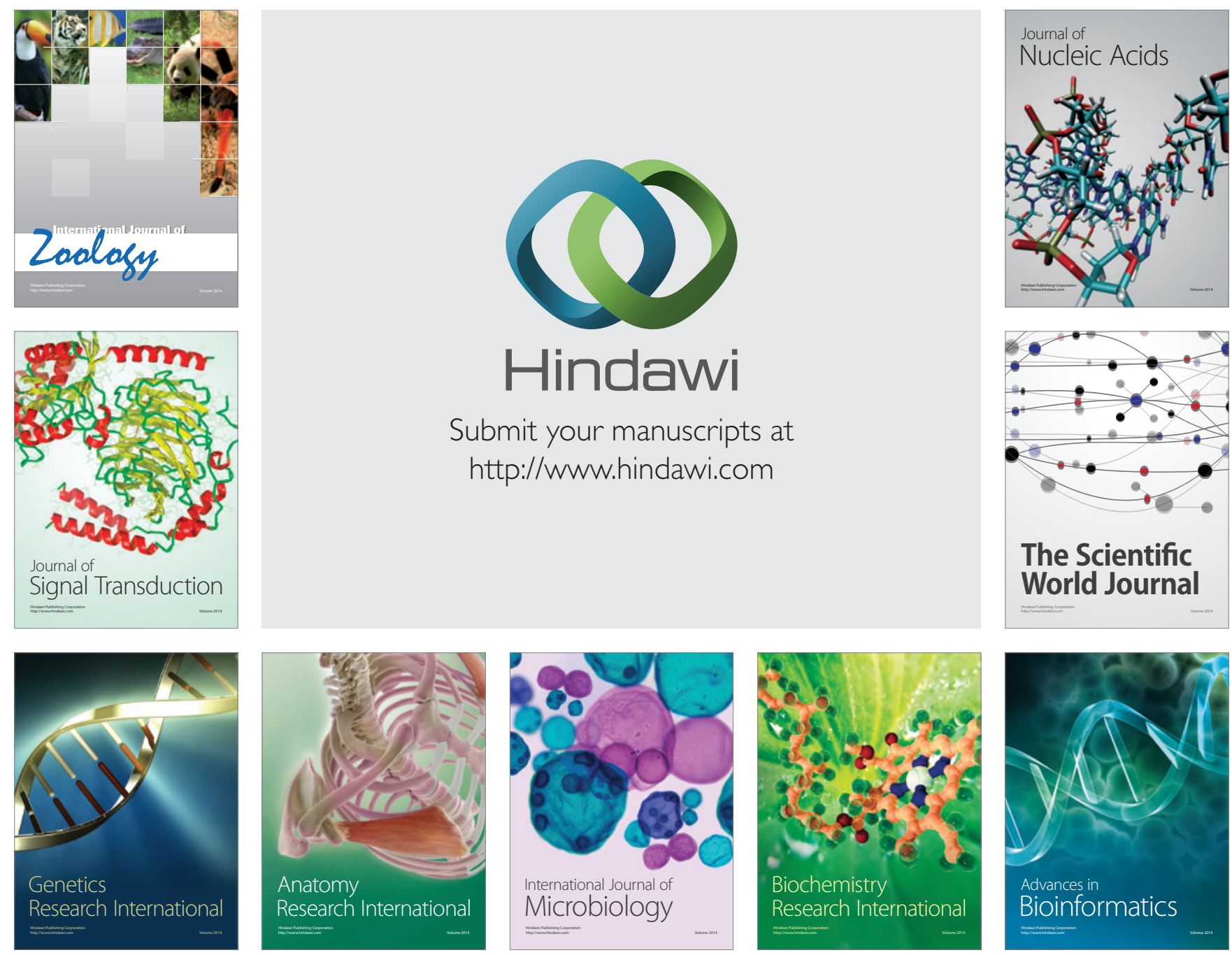

The Scientific World Journal
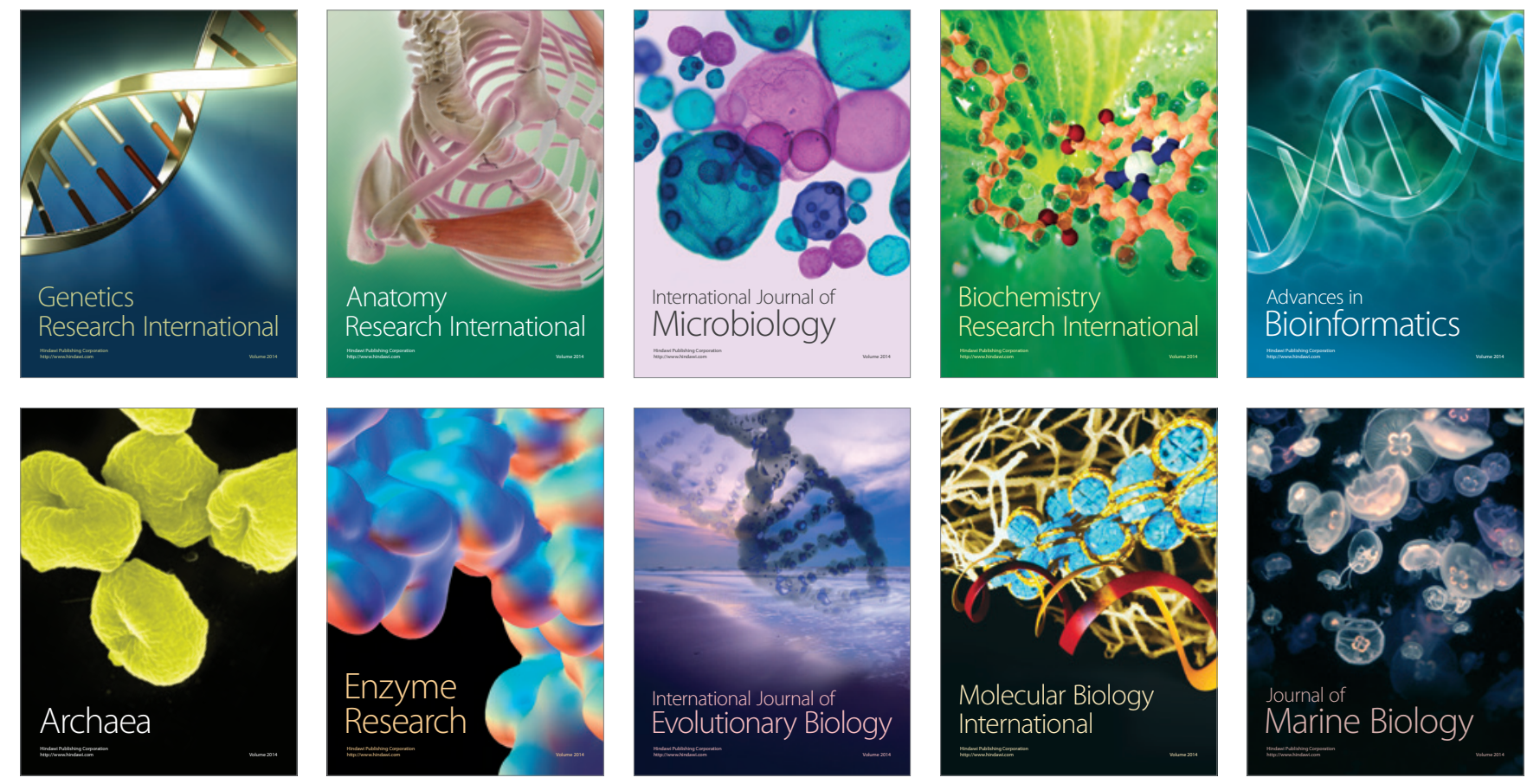